\title{
Food of the cladoceran Podon intermedius in a marine embayment
}

\author{
Richard A. Jagger*, William J. Kimmerer**, Greg P. Jenkins*** \\ Department of Zoology, University of Melbourne, Parkville, Victoria 3052, Australia
}

\begin{abstract}
Diet of the marine cladoceran Podon intermedius from Port Phillip Bay, Australia, was studied using feeding experiments and scanning electron microscopic examination of faecal pellets. The most common prey items identified in faecal pellets were large diatoms, mainly Rhizosolenia sp. This genus was also the dominant diatom in the environment at the time of sampling. Animal remains were not found in the faecal pellets. Phytoplankton of various sizes were offered to $P$. intermedius in feeding experiments, but significant feeding only occurred on Rhizosolenia. P. intermedius is apparently a raptorially-feeding herbivore.
\end{abstract}

\section{INTRODUCTION}

Marine cladocerans can represent a major proportion of the coastal zooplankton, sometimes exceeding copepods in abundance (Bosch \& Taylor 1973). Three cladoceran genera are widely represented in the marine environment (Onbe 1977). The family Sididae is represented by a single species, Penilia avirostris, and the remaining species are distributed between the genera Evadne and Podon, in the family Podonidae. $P$. avirostris is known to feed exclusively on small particles (Paffenhöfer \& Orcutt 1986), but knowledge of the feeding ecology of the Podonidae is very limited.

The Podonidae have been classified as either raptorial carnivores, based on their prominent compound eye (Russell-Hunter 1979), or as phytoplankton grazers, based on gut colouration and on particles caught in the feeding appendages (Lebour 1922, Bainbridge 1958). Turner (1984a) summarised knowledge of feeding in marine cladocerans as 'somewhat contradictory'. Recent studies of podonid mouthparts using a scanning electron microscope (SEM) (Nival \& Ravera 1979, 1981) revealed that these animals probably consume food particles of 20 to $170 \mu \mathrm{m}$ diameter. This range would

Present addresses:

- I.M.C.R., 24 Love St, Black Rock, Victoria 3193, Australia

- Biosystems Analysis Inc., Golden Gate Energy Center, Bldg 1065, Ft Cronkite, Sausalito, California 94965, USA

.. Division of Fisheries Research, CSIRO Marine Laboratories, GPO Box 1538, Hobart, Tasmania 7001, Australia include microzooplankton such as tintinnids and copepod nauplii, and larger phytoplankton cells.

In Port Phillip Bay, Australia, marine cladocerans make up an average of $23 \%$ of the zooplankton numbers (Kimmerer \& McKinnon 1985). Podon intermedius Lilljeborg is present in Port Phillip Bay all year (Kimmerer \& McKinnon 1985), with maximum abundances occurring in winter. In this study we examined the diet of $P$. intermedius from Port Phillip Bay. The contents of its faecal pellets were examined for prey remains, and various phytoplankton taxa were offered in feeding experiments.

\section{MATERIALS AND METHODS}

Scanning electron microscopy. Live Podon intermedius were collected from the northern end of Port Phillip Bay (Kimmerer \& McKinnon 1985: Station K) on 5 and 16 September and 2 October 1985. Surface tows of 5 min duration were taken with a $0.8 \times 0.8 \mathrm{~m}$ opening, $333 \mu \mathrm{m}$ mesh net (Jenkins 1986). Cladocerans were immediately transferred to containers of glass-fibrefiltered seawater. Faecal pellets from at least 30 individuals were examined on each date. After faecal pellets had been egested, specimens were removed and pellet remains placed into Petri dishes containing seawater filtered through a $10 \mu \mathrm{m}$ mesh. Natural bacteria were allowed to break down faecal pellets for 24 to $30 \mathrm{~h}$ (Turner $1984 \mathrm{~b}$ ). The pellets were then washed with distilled water to remove salt, and either dehy- 
drated through an alcohol series followed by critical point drying (Paerl \& Shimp 1973), or air dried for several days. The pellets were transferred to SEM stubs on glass-fibre filters and fastened by carbon glue, or placed directly onto the stubs and secured with a liquid adhesive. The remains of faecal pellets from over 100 individuals were viewed with a Phillips 505 Scanning Electron Microscope at 15 to $30 \mathrm{kV}$, and pellets containing identifiable remains were photographed. Analysis of faecal pellet remains was qualitative only, for the reasons outlined by Turner (1984c).

Feeding experiments. Live specimens were collected approximately weekly at Station $K$ from May to October 1985. The contents of the net cod end were transferred to opaque insulated buckets containing surface seawater collected at the same site. In the laboratory, the buckets were placed in a constant temperature room at approximately ambient water temperature.

Experiments were usually begun within a few hours of collection, and never longer than $30 \mathrm{~h}$ after collection. Parthenogenetic females ranging from 0.4 to 0.8 $\mathrm{mm}$ in standard length (see Onbe 1983) were used for experiments. Specimens were incubated in 120 or 250 $\mathrm{ml}$ clear glass bottles on a wheel rotating at $2 \mathrm{rpm}$. The experiments were performed as close as possible to ambient seawater temperature with a light/dark cycle of $16: 8 \mathrm{~h}$, usually over a $24 \mathrm{~h}$ period. Food included the flagellate Tetraselmis chui $(8 \mu \mathrm{m})$, the dinoflagellate Prorocentrum gracile $(40 \times 15 \mu \mathrm{m})$, and the diatom Hemiaulus sp. $(60 \mu \mathrm{m})$, which were cultured in the laboratory and maintained in an $\mathrm{f} / 2$ nutrient medium (Guillard \& Ryther 1962); and Rhizosolenia sp. (150× $10 \mu \mathrm{m}$ ) physically separated from samples collected from the surface at Station $\mathrm{K}$ using a $0.5 \mathrm{~m}$ diameter net with a $50 \mu \mathrm{m}$ mesh.

Phytoplankton for the feeding experiments were mixed thoroughly in filtered $(1 \mu \mathrm{m})$ seawater, and nutrients ( $\mathrm{f} / 2$ nutrient medium) were added in an attempt to reduce the effect of excretion of nutrients by experimental cladocerans on phytoplankton growth. All. experiments included controls with no Podon intermedius added. Samples of the phytoplankton suspension from experimental and control bottles were filtered onto glass-fibre filter papers and stored below $0{ }^{\circ} \mathrm{C}$ in acetone. The samples were later analysed for chlorophyll and phaeopigment by in vitro fluorometry (Strickland \& Parsons 1972) using a Turner model 110 fluorometer. In most cases, 5 individuals of $P$. intermedius were added to the $120 \mathrm{ml}$ bottles, although occasionally 10 were placed in 120 or $250 \mathrm{ml}$ bottles.

Although estimates of clearance rate were not the goal of the study, we did calculate clearance rates in the experiments with Rhizosolenia sp. using Frost's (1972) equations.

\section{RESULTS}

\section{Scanning electron microscopy}

The faecal pellets of Podon intermedius take the form of small, irregularly shaped pieces, unlike the smooth cylindrical form of copepod faecal pellets. In the majority of pellets with recognisable remains, fragments of the diatom Rhizosolenia sp. were present (Fig. 1a, b). Fragments of the diatom Hemiaulus sp. (Fig. 1c), and cells of the diatoms Amphora (Fig. 1d) and Entomoneis sp. (Fig. 2a, b), were occasionally found. Diatoms visible in Fig. $2 c$ could not be identified. Other remains appeared to be masses of amorphous particles (Fig. 2d). We found no animal remains in faecal pellets examined.

\section{Feeding experiments}

In the feeding experiments, Podon intermedius showed no significant feeding on Tetraselmis chui (Table $1_{i}$ t-test, $p>0.05$ ). However, in extremely high concentrations of $T$. chui $\left(50 \mu \mathrm{g} \mathrm{chl} \mathrm{l}^{-1}\right)$, individuals of $P$. intermedius were found to have cells of this flagellate in their guts. No significant feeding occurred when the cladocerans were exposed to Prorocentrum gracile or Hemiaulus sp. (Table 1). In 2 of 3 experiments using the diatom Rhizosolenia sp., however, significant feeding occurred. In the second experiment, standard deviations of both treatments and controls were large. Clearance rates per individual in the 3 experiments using Rhizosolenia were 12, 2 and $5 \mathrm{ml}$ $d^{-1}$, respectively.

\section{DISCUSSION}

Previous inferences on feeding in marine cladocerans have mainly been based on anecdotal observations. Lebour (1922) found soft brown remains with no apparent structure in Evadne nordmanni guts. Bainbridge (1958) observed 'reddish' or 'brownish' debris in the guts of $E$. nordmanni, and because no cell structures were present, he concluded that only cell contents were ingested, while hard remains were discarded. The tooth-like structures found on the mandible of Evadne spinifera (Nival \& Ravera 1979) and other marine cladocerans (Meurice \& Dauby 1983) may suggest that this is possible. However, our results show that some ingestion of frustules does occur

The results of the feeding experiments with Tetraselmis chui supports the conclusions of Nival \& Ravera $(1979,1981)$ that smaller particles cannot be handled efficiently by podonids. Ingestion of cells of $T$ chui, 


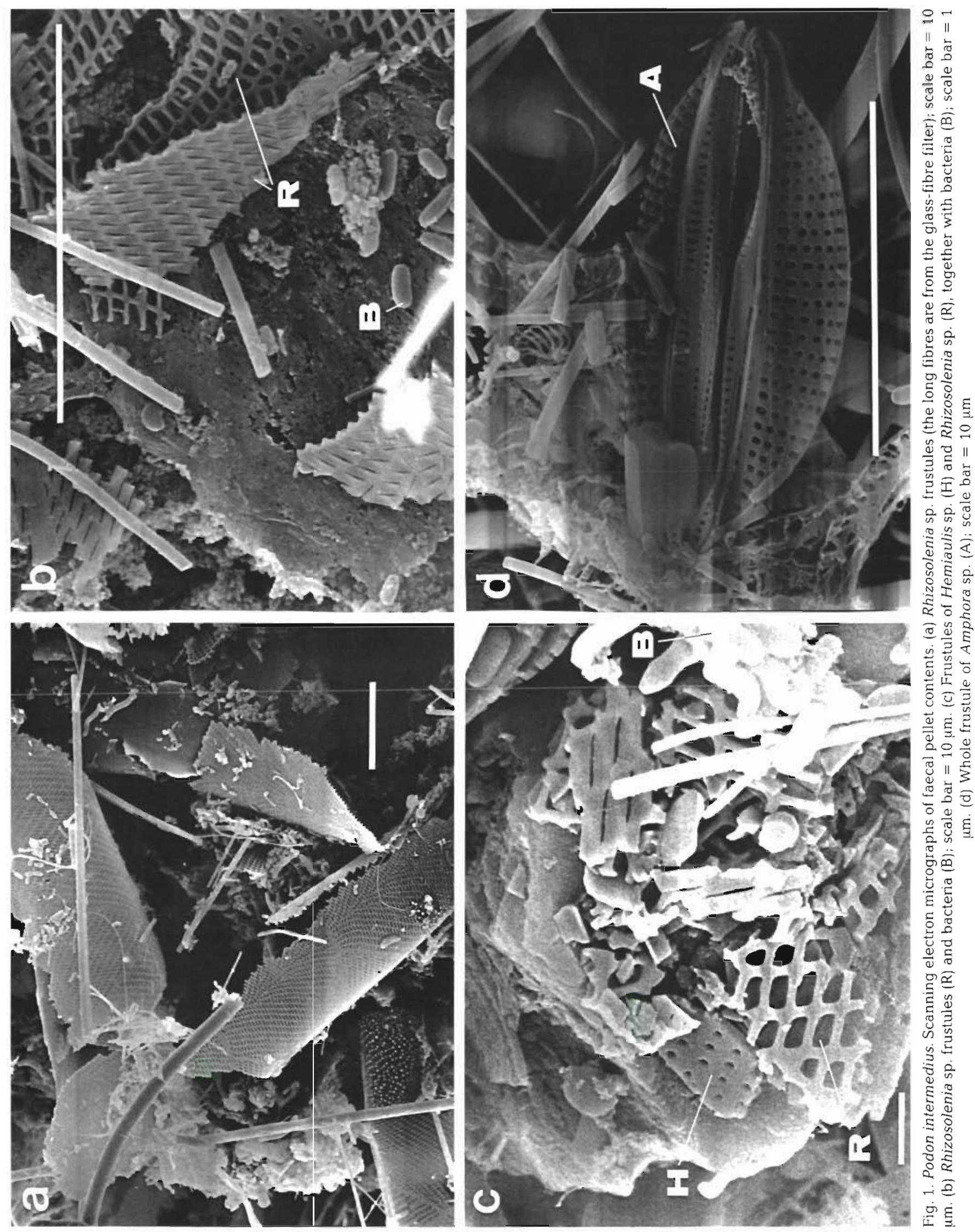



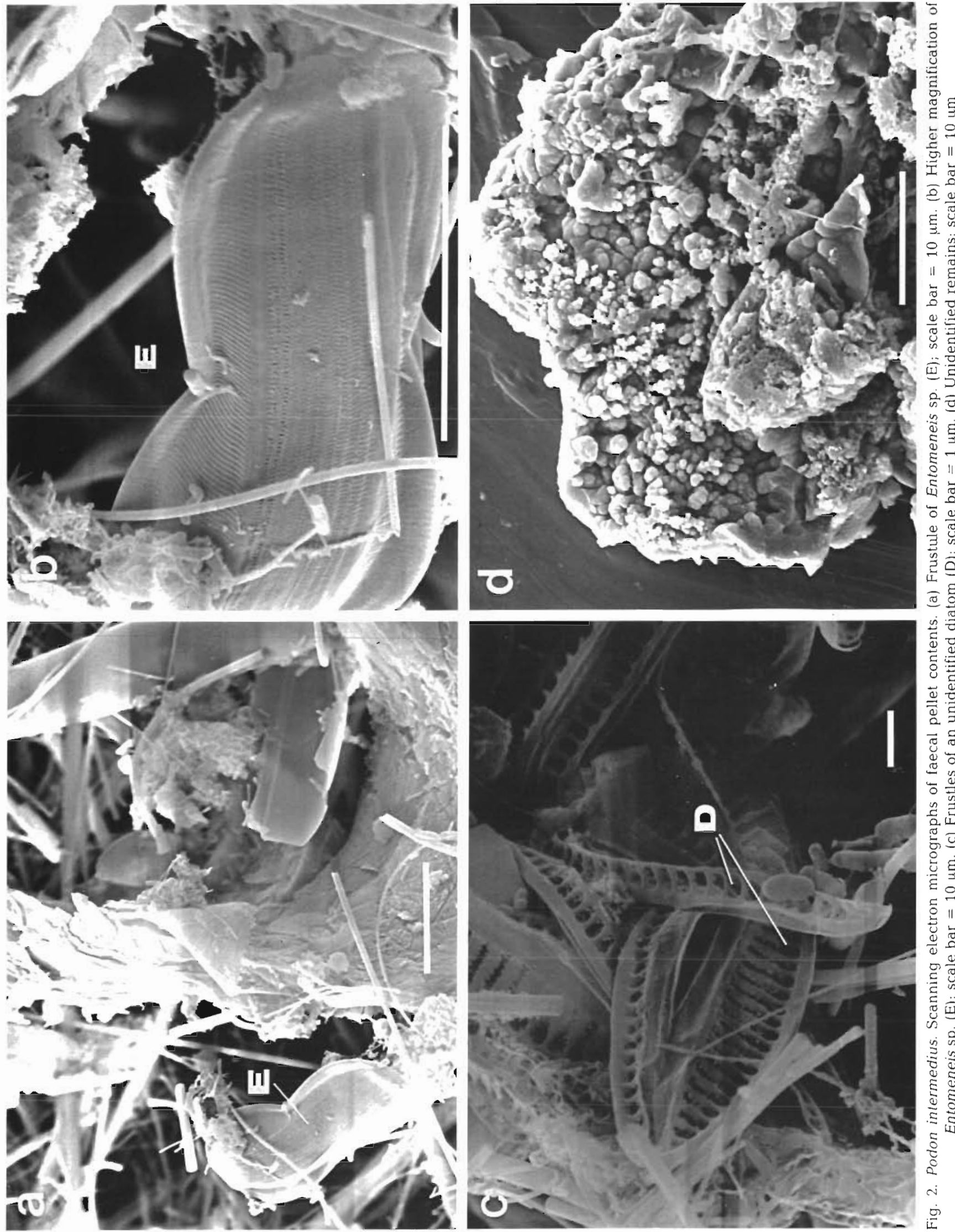
Table 1 Podon intermedius. Results of feeding experiments; chlorophyll concentrations in experimental and control bottles after incubation

\begin{tabular}{|c|c|c|c|c|c|c|c|c|c|}
\hline \multirow[t]{2}{*}{ Food item } & \multirow{2}{*}{$\begin{array}{c}\text { Podon } \\
\text { bottle }\end{array}$} & \multirow{2}{*}{$\begin{array}{c}\text { Bottle size } \\
\qquad(\mathrm{ml})\end{array}$} & \multicolumn{3}{|c|}{ Experimental $\left(\mu \mathrm{g} \mathrm{chl} \mathrm{l}^{-1}\right)$} & \multicolumn{3}{|c|}{ Control ( $\mu \mathrm{g} \mathrm{chl} \mathrm{1^{-1 } )}$} & \multirow[t]{2}{*}{$p(t$-test $)$} \\
\hline & & & $n$ & Mean & SD & $n$ & Mean & $\mathrm{SD}$ & \\
\hline Tetraselmis chui & 5 & 120 & 13 & 1.74 & 0.37 & 6 & 1.76 & 0.16 & $>0.05$ \\
\hline Tetraselmis chui & 10 & 250 & 5 & 1.65 & 0.32 & 4 & 1.47 & 0.68 & $>0.05$ \\
\hline Tetraselmis chui & 5 & 120 & 14 & 0.36 & 0.08 & 6 & 0.38 & 0.08 & $>0.05$ \\
\hline Tetraselmis chui & 10 & 250 & 4 & 0.35 & 0.01 & 4 & 0.35 & 0.08 & $>0.05$ \\
\hline Tetraselmis chui & 5 & 120 & 10 & 0.35 & 0.06 & 10 & 0.31 & 0.05 & $>0.05$ \\
\hline Tetraselmis chui & 5 & 120 & 7 & 0.19 & 0.06 & 7 & 0.23 & 0.06 & $>0.05$ \\
\hline Hemiaulus sp. & 5 & 120 & 10 & 0.60 & 0.23 & 8 & 0.50 & 0.11 & $>0.05$ \\
\hline Prorocentrum gracile & 5 & 120 & 5 & 2.85 & 0.24 & 5 & 2.76 & 0.23 & $>0.05$ \\
\hline Prorocentrum gracile & 10 & 120 & 5 & 2.65 & 0.23 & 5 & 2.76 & 0.23 & $>0.05$ \\
\hline Prorocentrum gracile & 10 & 120 & 9 & 0.73 & 0.17 & 8 & 0.68 & 0.10 & $>0.05$ \\
\hline Rhizosolenia sp. & 5 & 120 & 5 & 2.37 & 0.63 & 5 & 3.89 & 1.34 & $<0.05$ \\
\hline Rhizosoleniasp. & 5 & 120 & 8 & 19.00 & 6.97 & 8 & 20.77 & 8.06 & $>0.05$ \\
\hline Rhizosolenia sp. & 5 & 120 & 8 & 8.70 & 1.31 & 8 & 10.62 & 1.57 & $<0.01$ \\
\hline
\end{tabular}

when this food was offered at high concentrations, could have been due to an increase in chance ingestion, or to clumping of cells.

The dominance of Rhizosolenia sp. in the diet of Podon intermedius is a reflection of the fact that this diatom was highly concentrated at the surface throughout the period of sampling (27 to 41 cells $\mathrm{ml}^{-1}$ ). $P$. intermedius may not consume all phytoplankton of a suitable size, for although Ceratium sp. was often very abundant at the time of sampling, no remains of this dinoflagellate were found in faecal pellets.

No evidence for predation on other zooplankton was found in this study. Hard remains of some zooplankters, such as crustacean exoskeletons or tintinnid loricae, would be visible in faecal pellets if they were present (see Turner \& Anderson 1983, Turner 1984b), although this method would not detect soft-bodied organisms such as naked ciliates. Observations on feeding appendages (Nival \& Ravera 1981) indicate that this species is possibly a raptorial feeder. However, Podon intermedius may not be sufficiently active to capture zooplankters with well-developed escape responses.

The results of this study may provide an explanation for the lack of a resident population of Podon intermedius, or other species of marine cladoceran, in Westemport Bay, which is adjacent to port Phillip Bay (Kimmerer \& McKinnon 1985). The particle suspension in Westernport Bay consists mainly of detrital remains of seagrasses and small phytoplankton. Diatoms large enough to be ingested efficiently by $P$. intermedius make up only a small proportion of the total chlorophyll in Westernport Bay (Kimmerer \& McKinnon 1987); thus suitable feeding conditions for $P$. intermedius may not occur there.
Acknowledgements. We are grateful to M. Fancett for assistance with field work. We thank Dr J. Turner, D. McKinnon and M. Fancett for commenting on drafts of this manuscript. We also thank J. Coyne for assistance with SEM operation and B. Carr for photographic work.

\section{LITERATURE CITED}

Bainbridge, V (1958). Some observations on Evadne nordmanni Loven. J. mar. biol. Ass. U. K. 37: 349-370

Bosth, H. F., Taylor, W. R. (1973). Distribution of the cladoceran Podon polyphemoides in the Chesapeake Bay. Mar. Biol. 19: 161-171

Frost, B. W. (1972). Effects of size and concentration of food particles on the feeding behavior of the marine planktonic copepod Calanus pacificus. Limnol. Oceanogr. 17: 805-815

Guillard, R. R. L., Ryther, J. H. (1962). Studies on marine planktonic diatoms. 1. Cyclotella nana Hustedt and Detonula confervacea Cleve. Can. J. Microbiol. 8: 229-239

Jenkins, G. P. (1986). Composition, seasonality and distribution of ichthyoplankton in Port Phillip Bay, Victoria. Aust. J. mar Freshwat. Res. 37: 507-520

Kimmerer, W. J., McKinnon, A. D. (1985). A comparative study of the zooplankton in two adjacent embayments, Port Phillip and Westernport Bays, Australia. Estuar. coast. Shelf Sci. 21: 145-159

Kimmerer, W. J., McKinnon, A. D. (1987). Growth, mortality and secondary production of the copepod Acartia tranteri in Westernport Bay, Australia. Limnol. Oceanogr. 32: $14-28$

Lebour, M. V. (1922). The food of plankton organisms. J. mar. biol. Ass. U. K. 12: 644-677

Meurice, J., Dauby, P. (1983). Scanning electron microscope study and computer analysis of taxonomic distances of the marine Podonidae (Cladocera). J. Plankton Res. 5: 787-795

Nival, S., Ravera, S. (1979). Morphological study of the appendages of the marine cladoceran Evadne spinifera Muller by means of the scanning electron microscope. J. Plankton Res. 1: 207-313

Nival, S., Ravera, S. (1981). An assessment of the feeding 
potentialities of two planktonic cladocerans, Podon intermedius Lilljeborg and Podon (Pleopsis) polyphemoides Leuckart (Crustacea, Branchiopoda), by means of a scanning electron microscope study of the functional morphology of cuticular structures. Annls Inst. oceanogr., Paris 57: $31-40$

Onbe, T. (1977). The biology of marine cladocerans in a warm temperate water. Proceeding Symposium Warm Water Zooplankton, Spec. Publ. UNESCO/Nat. Inst. Oceanogr Goa, p. 383-398

Onbe, T. (1983). Preliminary observations on the biology of a marine cladoceran Pleopsis ('Podon') schmackeri Poppe. J. Fac. Appl. Biol. Sci., Hiroshima Univ. 22: 55-64

Paerl, H. W., Shimp, S. L. (1973). Preparation of filtered plankton and detritus for study with scanning electron microscopy. Limnol. Oceanogr. 18: 802-805

Paffenhöfer, G.-A., Orcutt, J. D. (1986). Feeding, growth and food conversion of the marine cladoceran Penilia avirostris J. Plankton Res. 8: 741-754
Russell-Hunter, W. D. (1979). A life of invertebrates. Macmillan Publishing Co., New York

Strickland, J., Parsons, T (1972). A practical handbook of seawater analysis. Bull. Fish. Res. Bd Can. 167 1-311

Turner, J. T (1984a). The feeding ecology of some zooplankters that are important prey items of larval fish. NOAA Technical Report NMFS 7: 1-28

Turner, J. T (1984b). Zooplankton feeding ecology: contents of fecal pellets of the copepods Eucalanus pileatus and Paracalanus quasimodo from continental shelf waters of the Gulf of Mexico. Mar. Ecol. Prog. Ser. 15: 27-46

Turner, J. T. (1984c). Zooplankton feeding ecology: contents of fecal pellets of the copepods Acartia tonsa and Labidocera aestiva from continental shelf waters near the mouth of the Mississippi River. P. S. Z. N. I: Mar. Ecol. 5: 265-282

Turner, J. T., Anderson, D. M. (1983). Zooplankton grazing during dinoflagellate blooms in a Cape Cod embayment, with observations of predation upon tintinnids by copepods. P. S. Z. N. I: Mar Ecol. 4: 359-374

This article was submitted to the editor; it was accepted for printing on January 8, 1988 